\title{
LANGUAGE VARIATION IN LEXICAL VARIABLES OF MADURESE TERMS OF ADDRESS USED BY YOUTHS IN BONDOWOSO REGENCY: A SOCIOLINGUISTIC INVESTIGATION
}

\author{
Alfi Hidayatu Miqawati \\ Politeknik Negeri Jember \\ alfi_hidayatu@polije.ac.id
}

Submit, 29-11-2019 Accepted, 25-12-2019 Publish, 25-12-2019

\begin{abstract}
This study attempts to investigate the usage of address terms among youths (university students) across a range of situations in Bondowoso. A qualitative method with an ethnographic approach was deployed. Fifteen most representative students were taken as the source of data. The data were obtained through participatory and non-participatory observation interviews, and a questionnaire. The findings show that the students employ different terms of address, both when they address people and when they address themselves for others. The ways of addressing other people used are based on their age, social or educational status, and or their kinship relationship. The terms to address others and to address themselves for others are classified into four levels; the least polite, polite, more polite, and the most polite. They use be'na or be'en, sampeyan/sampiyan, panjenengan, ajunan to address others and engkok/sengkok, kaule, dhalem, and abdina to address themselves to others. In addition, the lexical variation occuring when they address people using the least polite way is based on their geographical distribution. From the findings, it can be concluded that politeness strategy in terms of address among youths in Bondowoso exists and its implementation varies depending on their interlocutors (social) and the subdistricts where they live (geographical.
\end{abstract}

Keywords: terms of address, politeness strategy, youths, Madurese language

\section{INTRODUCTION}

Language and culture link together. Language expresses cultural reality (people express facts and ideas as well as reflect their attitudes with words), embodies cultural identity (people give meaning to their experience through the means of communication), and symbolizes cultural reality (people view their language as a symbol of their social identity) (Kramsch \& Widdowson, 1998). The bound becomes one of the factors that promote language variation. 
As stated by (Wardhaugh, 2011), variation in language may depend on different factors; styles (the situation in which the speech act takes place and according to the relation between the speakers), register (specific functions in particular situations), and geographical and social background of the speaker. Sociolinguists have also looked at the varying usage of lexical items. The uses of language variation can be found in many social interactions. One of them is the use of terms of address which are essential in addressing someone, has significant social functions, can establish, maintain and reinforce all kinds of interpersonal relations.

Terms of address serve as a means to show politeness in social interaction and cultural practices. (Ouafeu, 2006), delineated that politeness strategies are universal and that speakers of each language, in general, "make use of similar strategies to express a wide range of attitudinal functions". Meanwhile, Watt (2003) noted that politeness is characterized according to people's perceptions, as a behavior that shows respect to others or evaluates someone as polite by looking at the language used.

In the Asian context, where the societies are mostly stratified, the use of address forms during interaction plays an important role. A study conducted by (Hei, David, Kia, \& Soo, 2011) showed that, in Malay society, the use of titles or honorifics are often used to indicate the social status of certain individuals. Meanwhile, (Gan, David, \& Dumanig, 2015) revealed another finding showing that Filipino domestic helpers working in Malaysia deploy particular politeness strategies by addressing their employers with many address forms, depending on their relationshi p, social distance, age, and the Filipino, Malaysian, and Western cultures.

Communication accurs accross gender, cultures, age, and nationality. Youths, as part of the community also has an essential role in building communication and maintaining local wisdom. Studies by (Arapah \& Mu'in, 2017; Arini, 2016) about terms of address used by Banjarese youths (including university students) revealed that there are three levels of politeness used in addressing the older people in Banjarese, from the most polite, the less polite, and the least polite. Each of them is used to indicate the social status or the relation of the speaker and other persons in the discourse. However, not many more studies focusing on local language communications among youths in Indonesia are conducted.

Madurese, the language spoken by Madurese ethnic (one of the ethnics in Indonesia having a strong social interaction that affects the use of language in daily communication), is not only used by people living in Madura but also mostlyby people living in Tapal Kuda region (Jember, Bondowoso, Situbondo, and Bondowoso Districs). A study conducted by Haryono \& Wibisono (2018). 
revealed that language variation in Madurese terms of address in Tapal Kuda region is as the politeness implementation form and formal relationship among speech participants and as intimacy and close relationship between parents and children. However, their study only focused on finding speech level in family domain and language variety used by husband-wife and by children to parents.

All in all, the existing studies about terms of address used by Indonesian youths have not provided adequate information, especially in the context of communications using local languages. Thus, this study attempts to investigate the current trends in the usage of address terms among youths (university students) across a range of situations in one of the cities located in Tapal Kuda region, Bondowoso.

\section{LITERATUR REVIEW}

\section{Terms of Address and Politeness Strategy in Communication}

Speech behavior is a characteristic feature of communicative culture, that determines the choice of formulae and models of everyday communication, revealing people's class and social status and operating within politeness strategy of socio-pragmatic conditions (Ryabova, 2015). (Haryono, 2018) stated that in a speech community, there are certain group members who are necessary to be respected in speaking, but in certain social groups it is not necessary to give a special honour. Therefore, aspeech level may occur and can be categorized into respectful form and casual form. The factors driving the use of these speech levels are somehow varied and different from one society to another, such as physicality, economic power, social status, power, political influence, intimacy, age, sex, and physiological condition. In Madurese context, there are several speech levels with their lexical variable in addressing others which are applied in communication and indicate politeness and respect. Table 1 show the Madurese speech level

Table 1. Madurese Language Speech Level

\begin{tabular}{|c|c|c|c|c|c|}
\hline \multirow{2}{*}{$\begin{array}{c}\text { Speech } \\
\text { Level/ } \\
\text { Variaton }\end{array}$} & \multirow{2}{*}{$\begin{array}{c}\text { Participant } \\
\text { Relationship }\end{array}$} & \multirow[t]{2}{*}{ Use } & \multicolumn{3}{|c|}{ Examples of Word Use } \\
\hline & & & I & You & Yes \\
\hline $\begin{array}{l}\text { enjấ'-iyâ } \\
(\mathrm{E}-\mathrm{I})\end{array}$ & $\begin{array}{l}\text { the same age } \\
\text { or the speaker } \\
\text { is older; very } \\
\text { close }\end{array}$ & $\begin{array}{l}\text { with close } \\
\text { friend; } \\
\text { parents to } \\
\text { children }\end{array}$ & sèngko' & bâ'na & $i y \hat{a}$ \\
\hline $\begin{array}{l}\text { engghi-enten } \\
\text { (E-E) }\end{array}$ & $\begin{array}{l}\text { the speaker is } \\
\text { younger with } \\
\text { not so far } \\
\text { social status }\end{array}$ & $\begin{array}{l}\text { same adult } \\
\text { who just } \\
\text { knew, to } \\
\text { parents }\end{array}$ & kaulâ & $\begin{array}{c}\text { sampèya } \\
n\end{array}$ & $\begin{array}{c}\text { enggh } \\
i\end{array}$ \\
\hline
\end{tabular}




\begin{tabular}{|c|c|c|c|c|c|}
\hline $\begin{array}{l}\text { èngghi- } \\
\text { bhunten } \\
\text { (̇̀-B) }\end{array}$ & $\begin{array}{l}\text { the speaker is } \\
\text { younger with } \\
\text { far enough } \\
\text { social status; } \\
\text { often in } \\
\text { interaction }\end{array}$ & $\begin{array}{l}\text { to superior, } \\
\text { to parents in } \\
\text { law }\end{array}$ & $\begin{array}{c}\text { bhâdhânkau } \\
\text { lâ }\end{array}$ & $\begin{array}{c}\text { panjhann } \\
\text { engngan }\end{array}$ & $\underset{i}{\grave{e} n g g h}$ \\
\hline $\begin{array}{l}\text { bhâsaalos } \\
\text { (BAl) }\end{array}$ & $\begin{array}{l}\text { the speaker } \\
\text { with very far } \\
\text { social status; } \\
\text { never in } \\
\text { interaction }\end{array}$ & $\begin{array}{l}\text { to kiyai; to } \\
\text { lord }\end{array}$ & $\begin{array}{l}\text { dâlom/ } \\
\text { abdhina }\end{array}$ & $\begin{array}{l}\text { Ajunan, } \\
\text { padhâna }\end{array}$ & $\begin{array}{c}\text { dhâla } \\
m\end{array}$ \\
\hline $\begin{array}{l}\text { engghè-enten } \\
\text { (Eg-E) }\end{array}$ & $\begin{array}{l}\text { the speaker is } \\
\text { older; often in } \\
\text { interaction }\end{array}$ & $\begin{array}{l}\text { parents in } \\
\text { law to son/ } \\
\text { daughter in } \\
\text { law; } \\
\text { younger } \\
\text { neighbor }\end{array}$ & bulâ & Dhika & $\begin{array}{c}\text { enggh } \\
e\end{array}$ \\
\hline $\begin{array}{l}\text { bhâsaMalaju } \\
\text { (ragam kota) } \\
\text { (BMlj) }\end{array}$ & $\begin{array}{l}\text { rather close, no } \\
\text { family } \\
\text { relationship }\end{array}$ & $\begin{array}{l}\text { school/offic } \\
\text { e mate, } \\
\text { other } \\
\text { ethnics }\end{array}$ & saya & Situ & iya \\
\hline
\end{tabular}

(Sofyan, 2016 as adapted by (Haryono, 2018)

\section{RESEARCH METHOD}

This research deployed a qualitative method with an ethnographic approach. Participatory and non-participatory observation, interviews, and a questionnaire were used to collect the data needed in this present study. While conducting observations and interviews, sound and video recordings were done to anticipate the limitations in capturing the events and in listening as well as to document essential things during the study.

The information was obtained from the most representative source to collect sufficient data for this study. Fifteen students of two private universities in Bondowososo whose mother tongue is Madurese were taken as the source of information. They were born in Bondowoso, have not lived in other cities for a long period of time, and live in different sub-districts in Bondowoso (Prajekan, Cerme, Botolinggo, Klabang, Wonosari, Tlogosari, Pujer, Tamanan, Maesan, Jambesari Darus Sholah, Bondowoso, Grujugan, Wringin, Curahdami, and Sumberwringin).

After the data collection had been completed, the researcher started the identification of the variants and analysis of the questionnaires. The data were analyzed descriptively. Before being analyzed, the data were classified based on the topics of discussion. Source of data triangulation was conducted to increase reliability, validity, and accuracy 


\section{FINDING}

The questionnaire distributed comprised of two parts. The first part of the questionnaire meant to specify the participants' personal information. The next questions in the questionnaire inquired about the way that the respondents address other people and address themselves for others. The southern and eastern parts refer to sub-districts located close to Situbondo Regency (Prajekan, Cerme, Botolinggo, Klabang) while the western and southern parts refer to areas located close to Banyuwangi, Jember, and Situbondo (partial). The findings show that the respondents living in the southern and eastern parts of Bondowoso have different terms in addressing others and in addressing themselves to others compared with those living in the southern and western parts of Bondowoso. Picture 1 shows the map of Bondowoso Regency, Table 2 shows how they address others and Table 3 shows how they address themselves to others.

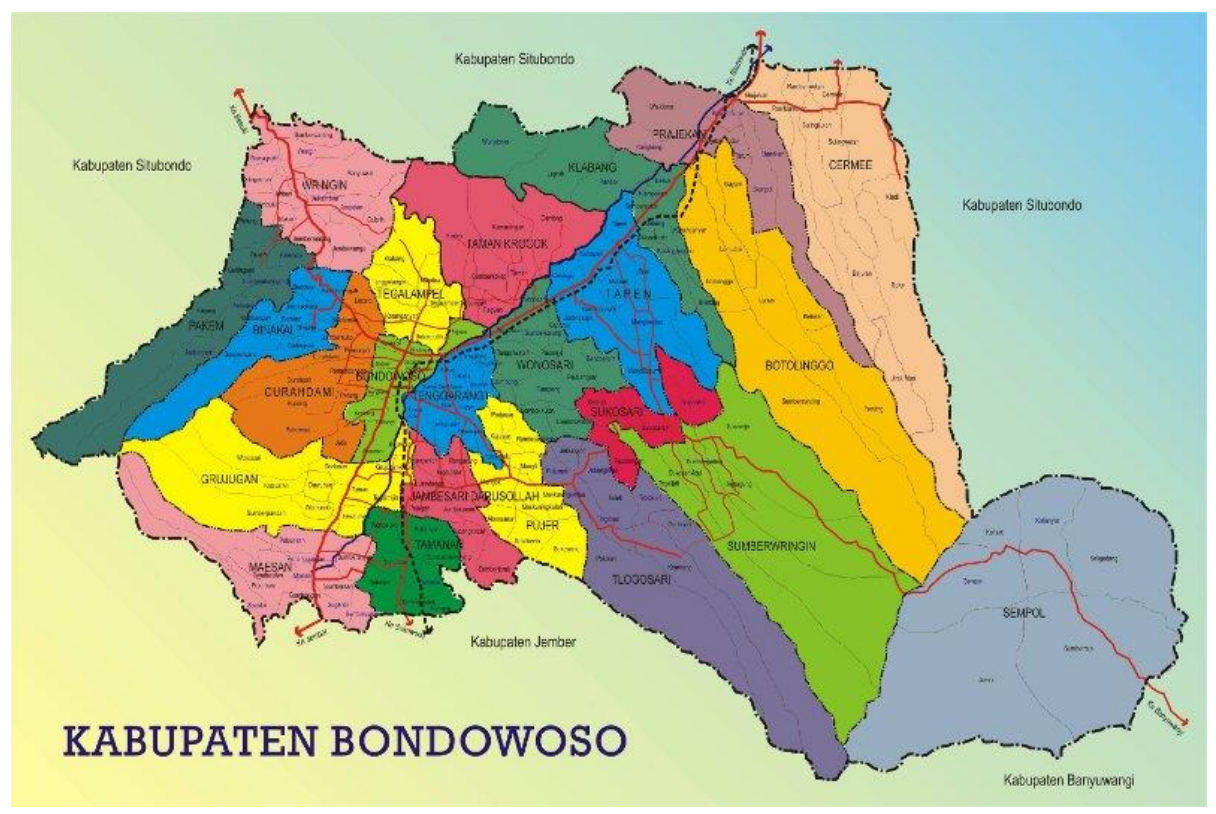

Picture 1. Map of Bondowoso

Table 2. How The Students Address Others

(The terms below are used to refer "you" in communication)

\begin{tabular}{lcc}
\hline \multicolumn{1}{c}{ Function } & $\begin{array}{c}\text { Southern and Eastern } \\
\text { Parts }\end{array}$ & $\begin{array}{c}\text { Western and } \\
\text { Northern Parts }\end{array}$ \\
\hline Least Polite & Be'na & Be'en \\
\hline Polite & Sampeyan/Sampiyan & Sampeyan/Sampiyan \\
\hline More Polite & Panjhənnengngan & Panjhənnengngan \\
\hline Most Polite & Ajunan & Ajunan \\
\hline
\end{tabular}


The participants from Cerme, Prajekan, Klabang, Botolinggo sub-districts (northern and eastern parts of Bondowoso) used be 'na, sampeyan/sampiyan, panjhannengngan, and ajunan to address others. Meanwhile, those living in Wonosari, Tlogosari, Pujer, Tamanan, Maesan, Jambesari Darus Sholah, Bondowoso, Grujugan, Wringin, Curahdami, and Sumberwringin Sub-districts (western and southern parts) used be'en, sampeyan/sampiyan, panjhannengngan, and ajunan to address others.

To address themselves, all the participants used the same terms in addressing themselves when communicating with others. The terms of address are sěngkok/ěngkok, kaule, dâlom, and abdhina.

Table 3. How The Students Address Themselves to Others (The terms below are used to refer "I" in communication)

\begin{tabular}{lcc}
\hline \multicolumn{1}{c}{ Function } & $\begin{array}{c}\text { Southern and Eastern } \\
\text { Parts }\end{array}$ & $\begin{array}{c}\text { Western and Northern } \\
\text { Parts }\end{array}$ \\
\hline Least Polite & Sĕngkok/ĕngkok & Sĕngkok/ĕngkok \\
\hline Polite & Kaule & Kaule \\
\hline More Polite & Dâlam & Dâlam \\
\hline Most Polite & Abdhina & Abdhina \\
\hline
\end{tabular}

\section{DISCUSSION}

\section{Terms of Address Used by The Students address others}

Less polite terms of address (be'na and be'en which means you)

In addressing others, all students agreed that they have different ways of addressing other people based on their age, social or educational status, and or their kinship relationship. In addressing someone younger, intimate friends or neighbors and colleagues, they use different terms. Those coming from Cerme, Prajekan, Klabang, and Botolinggo Sub-districts use be'na while those coming Wonosari, Tlogosari, Pujer, Tamanan, Maesan, Jambesari Darus Sholah, Bondowoso, Grujugan, Wringin, Curahdami, and Sumberwringin Sub-districts use be'en to address someone younger or intimate friends. The terms be'en and be'na have the same meaning, which is you. What becomes an important point to be highlighted is that when the students are engaged in communication with peers from different sub-districts, they can be addressed using both variations (be'na and be'en ), but they prefer to be addressed using the terms they use to address people. They found it quite harsh to be addressed using be'na when they address others using be'en. 
Polite terms of address (sampeyan or sampiyan which means you)

From the data collected, all the students said that they use the terms sampeyan or sampiyan to address older people, for example, older friends, older sister or brother, or a stranger who looks older than them. They use these terms of address to show their respect to the one they addressed. In this case, all of the students share the same ideas of addressing people.

1. More polite terms of address (panjenengan which means you). The third term of address is panjenenngan. The term is used to address much-respected people, such as parents, grandparents, teachers, and bosses. To respect those people, the students thought that panjenengan is the best way. Otherwise, they will be considered impolite.

2. Most polite terms of address (ajunan which means you). The last is ajunan. The term ajunan possesses the highest politeness rule in Madurese culture. Everybody cannot be easily addressed by this term. People use this term only to address spiritual teachers, pious, members of the pious' family and/or senior teachers. The students as the participants of this current study also agreed that they use this term to address kiai (Islamic religious leader).

\section{Terms of Address Used by The Students to Address Themselves for Others}

\section{Less polite terms of address (sengkok or engkok which means I)}

In addressing themselves to others, all respondents use the terms engkok or sengkok. There is no difference in meaning between the two. They use these terms interchangeably when they talk to someone younger, intimate friends, neighbor, and colleagues. Besides for the sake of politeness, the respondents point themselves by using this term to show intimacy to whom they talk to.

1. Polite terms of address (kaule which means I). The second term of address used is kaule. Different from the first term, it is more polite in term of condition. A speaker uses this kind of term to address themselves to older people, for example, parents, older friends, older sister or brother, or a stranger who looks older than them. The students use this term of address to show their respect to the one they addressed. In this case, all of the respondents in this study who come from different areas in Bondowoso share the same ideas of addressing people.

2. More polite terms of address (dâlam which means I). The third term used to address the speaker himself is dâlam. Compared to the previous two, it is much more polite. The term is used when someone is talking to much-respected people, such as parents, teachers, and bosses. From the data collected, only three out of the fifteen students used this term very often. The rest felt it weird to address themselves by using this term. They preferred to use the second term 
(kaule) or the fourth term (abdhina) because they thought it was more sensible and polite.

3. Most polite terms of address (abdhina which means I). The last term of address is abdhina. It is the most polite and acceptable term. A speaker addresses him/herself by using this word to show very high respect to whom they are talking and to put themselves in a prestigious position in society. Like the term ajunan, this term also possesses the highest politeness rule in Madurese culture. The students use this term not only to address spiritual teachers, pious, members of the pious' family and/or senior teachers but also to their senior family members or relatives.

The findings of this study are in line with the results of a research conducted by (Putri, 2017) that the use of those address of terms as the representation of the youths' language attitude of youths towards Madurese as their culture and identity indicates a positive sign. In addtions, the lexical variations in this study occur because of social and geographical factors. It can be inrerred that it supports the previous study by (Muttaqin, Sahiruddin, \& Rodliyah, 2019) that some variations of lexixon do occur as attributed to the socio-cultural background of each speaker and the level of politeness indicates that the social level influences the choice of lexical terms used by speakers based on different ages and regions in Madura.

\section{CONCLUSION}

A language expresses cultural reality and embodies cultural identity. There are many variations among languages and they are affected by many factors such as the situation in which the speech act takes place, the relation between the speakers, specific functions in particular situations, the geographical and the social background of the speaker.As a widely spoken language in Bondowoso, Madurese, based on its variation and dialect, is divided into two big groups as found in this study. The groups were divided based on their geographical distribution. The first group consists of people who live in the eastern and northern parts of Bondowoso and the second group consisted of people living in the southern and western parts of Bondowoso. In addressing people, there were four terms of address used (be'na or be'en, sampeyan/sampiyan, panjenengan, ajunan). The terms are arranged from the less polite one to the most polite one. To address themselves to other people, the students use engkok/sengkok, kaule, dhalem, and abdina. The use of those terms is for respecting others. Compared to the previous studies, this finding provides another insight that the terms used to address people vary depending on the place they live (geographical distribution), especially in the least polite level way of addressing someone. Students from the eastern and northern part of Bondowoso use be'na while the rest use be'en. 


\section{REFERENCES}

Arapah, E., \& Mu'in, F. (2017). Politeness in using Banjarese and American English personal subject pronouns by English Department students of Lambung Mangkurat University. Journal of Language Teaching and Research, 8(2), 253-270.

Arini, D. N. (2016). Politeness Distinction: Terms Of Address Used By Banjerese Youth In Daily Life. Langkawi: Journal of The Association for Arabic and English, 2(2), 233-248.

Gan, A. D., David, M. M. K., \& Dumanig, F. P. (2015). Politeness strategies and address forms used by Filipino domestic helpers in addressing their Malaysian employers. Language in India, 15(1), 46-73.

Haryono, A. (2018). Communication patterns among kiais of Nahdlatul Ulama in the Madurese ethnic group. Indonesian Journal of Applied Linguistics, 7(3), 714-726.

Hei, K. C., David, M. K., Kia, L. S., \& Soo, A. P. (2011). Openings and closings in front counter transactions of Malaysian government hospitals. The Journal of the South East Asia Research Centre for Communication and Humanities, 3, 13-30.

Kramsch, C., \& Widdowson, H. G. (1998). Language and culture. Oxford University Press.

Muttaqin, S., Sahiruddin, S., \& Rodliyah, I. N. (2019). Language Variations In Madurese across Regions and Age Groups: Looking at Syntactic and Lexical Variations among Regions and Age Groups. KLAUSA (Kajian Linguistik, Pembelajaran Bahasa, dan Sastra), 3(01), 45-56.

Putri, N. A. (2017). THe Language Maintenance and Language Shift of Madurese Stylistic Level Among Youths in Sumenep Regency, Madura Island, East Java. Language Contact and Language Change, 178-184.

Ryabova, M. (2015). Politeness Strategy in Everyday Communication. 6.

Wardhaugh, R. (2011). An introduction to sociolinguistics. John Wiley \& Sons. 